\title{
Harald Asmus • Ragnhild Asmus \\ Material exchange and food web of seagrass beds in the Sylt-Rømø Bight: how significant are community changes at the ecosystem level?
}

\begin{abstract}
Material exchange, biodiversity and trophic transfer within the food web were investigated in two different types of intertidal seagrass beds: a sheltered, dense Zostera marina bed and a more exposed, sparse $Z$. noltii bed, in the Northern Wadden Sea. Both types of Zostera beds show a seasonal development of aboveground biomass, and therefore measurements were carried out during the vegetation period in summer. The exchange of particles and nutrients between seagrass beds and the overlying water was measured directly using an in situ flume. Particle sedimentation [carbon (C), nitrogen $(\mathrm{N})$ and phosphorus $(\mathrm{P})$ constituents] from the water column prevailed in dense seagrass beds. In the sheltered, dense seagrass bed, a net particle uptake was found even on windy days (7-8 Beaufort). Dissolved inorganic $\mathrm{N}$ and orthophosphate were mainly taken up by the dense seagrass bed. At times of strong winds, nutrients were released from the benthic community to tidal waters. In a budget calculation of total $\mathrm{N}$ and total $\mathrm{P}$, the dense seagrass beds were characterised as a material sink. The seagrass beds with sparse $Z$. noltii were a source of particles even during calm weather. The uptake of dissolved inorganic $\mathrm{N}$ in the sparse seagrass bed was low but significant, while the uptake of inorganic phosphate and silicate by seagrasses and their epiphytes was exceeded by release processes from the sediment into the overlying water. Estimates at the ecosystem level showed that material fluxes of seagrass beds in the Sylt$\mathrm{R} \emptyset \mathrm{m} \varnothing$ Bight are dominated by the dense type of Zostera beds. Therefore, seagrass beds act as a sink for particles and for dissolved inorganic nutrients. During storms, seagrass beds are distinct sources for inorganic nutrients. The total intertidal area of the Sylt-Rømø Bight could be described as a sink for particles and a source for dissolved nutrients. This balance of the material budget was estimated by either including or excluding seagrass beds.
\end{abstract}

H. Asmus $(\bowtie) \cdot R$. Asmus

Alfred-Wegener-Institut für Polar- und Meeresforschung 25992 List, Sylt, Germany

e-mail: Hasmus@awi-bremerhaven.de
Including the subtidal part, the function of the ecosystem as a source for particles increased, supposing that all seagrass beds were lost from the area. During the vegetation period, seagrass beds act as a storage compartment for material accumulated in the living biomass of the community. There was great biodiversity among the plant and animal groups found in intertidal seagrass beds of the Sylt-Rømø Bay, representing $50-86 \%$ of the total number of species investigated, depending on the particular group. Since most species are not exclusively seagrass residents, the loss of intertidal seagrass beds would be of minor importance for biodiversity at the ecosystem level. Food web structure in seagrass beds is different from other intertidal communities. Primary production and detritus input is high, but secondary production is similar to that of unvegetated areas, although the relative importance of the trophic guilds is different. The loss of seagrass beds leads to profound alterations in the food web of the total ecosystem. Historical as well as recent changes in material fluxes and energy flow due to manmade alterations to the ecosystem are discussed.

Key words Seagrass beds - Particle fluxes $\cdot$ Nutrient fluxes $\cdot$ Species diversity $\cdot$ Trophic transfer

\section{Introduction}

Seagrass beds are characterised by a high productivity and biodiversity and are therefore of great ecological (den Hartog 1970; Phillips 1984; Phillips and Meñez 1988; Nienhuis 1992; Nienhuis et al. 1996) and economic value (Halliday 1995). Subtidal seagrasses, in particular, increase the species diversity of the ambient ecosystem (Heck et al. 1995) whereas in temperate areas the promoting effect of intertidal seagrass beds on species diversity is assumed to be low (den Hartog 1983). Present day research on the functioning of seagrass beds focuses on the growth and productivity of seagrass beds (van Lent et al. 1991; Buia et al. 1992; Terrados and Ros 1992; Olesen and Sand-Jensen 1994; Philippart 1995; 
Reyes et al. 1995; Duarte et al. 1996; Ibarra-Obando et al. 1997; Livingston et al. 1998). The importance of seagrass beds for epifauna (Schneider and Mann 1991; Webb and Parsons 1991; Gambi et al. 1992; Isaksson and Pihl 1992; Murphey and Fonseca 1995; Jernakoff and Nielsen 1998) and endofauna should not be underestimated (Kalejta and Hockey 1991; Somaschini et al. 1994; Valentine et al. 1994; Hughes et al. 2000). Recent research has revealed that seagrass beds are important habitats for fish (Sogard and Able 1991; Bell et al. 1992; Worthington et al. 1992; Ferrell et al. 1993; Connolly 1994a, b; Edgar and Shaw 1995a, b; Borg and Pihl 1997; Francour 1997). The nutrient demand of different seagrass species and their reactions to nutrient enrichment and eutrophication up to toxic levels of ammonium and nitrate have been investigated (Brix and Lyngby 1985; Burkholder et al. 1992; Fourqurean et al. 1992; Pedersen and Borum 1992, 1993; Hemminga et al. 1994; Lapointe et al. 1994; Pérez-Lloréns and Niell 1995; Short et al. 1995; van Lent et al. 1995; Agawin et al. 1996; Stapel et al. 1996; Alcoverro et al. 1997; Kraemer et al. 1997; Pedersen et al. 1997; Udy and Dennison 1997; van Katwijk et al. 1997; Rimmelin et al. 1998). The role of whole seagrass bed communities for the material exchange between bottom and overlying water at the ecosystem level is less well investigated (Caffrey and Kemp 1990, 1992; Williams 1990; Hemminga et al. 1991; Asmus et al. 1994; Erftemeijer and Middelburg 1995; Johnson and Johnstone 1995; Taylor et al. 1995a, b; Viaroli et al. 1996). However, there is strong evidence that seagrass beds are important for sediment stability (Fonseca 1989) and for the retention of particles (Bulthuis et al. 1984; Dauby et al. 1995), since the canopy of leaves diminishes wave energy and currents (Fonseca and Fisher 1986; Gambi et al. 1990; Fonseca and Calahan 1992). Losses of seagrass beds have been observed all over the world (den Hartog and Polderman 1975; Orth and Moore 1983; Giesen et al. 1990; Tomasko and Lapointe 1991; de Jonge and de Jong 1992; Nienhuis 1992; Walker and McComb 1992; Durako 1994), and these losses led to profound changes in the material budget of coastal ecosystems (Asmus $\mathrm{R}$ and Asmus H 1998), because of the key role of seagrass beds. If seagrass beds are lost, the food web of the ambient ecosystem is altered, and primary and secondary production, as well as the energy flow, decrease (Heck et al. 1995). On both sides of the North Atlantic, losses of seagrasses were found early in the 1930s due to the wasting phenomenon (den Hartog 1987). The subtidal stocks survived in closed embayments and fjords where salinity was reduced, as in the Baltic Sea (Giesen et al. 1990). In the Wadden Sea, only the intertidal seagrass beds have recovered and reestablished their former ecological function to some extent. Due to the extinction of seagrass beds, major ecosystem changes have probably occurred in the twentieth century. The decrease in seagrass beds also still continues in the intertidal region of the Wadden Sea. It is the aim of this study to evaluate the functional role of the still existing intertidal seagrass beds in the
Sylt-Rømø Bight at an ecosystem level. We therefore examine the material exchange, the diversity and the energy flow of a dense $Z$. marina bed, which is representative of dense $Z$. noltii and dense mixed stands of $Z$. noltii and Z. marina, and we also examine a sparse $Z$. noltii bed.

\section{Materials and methods}

\section{Site}

The investigation area, the Sylt-Rømø Bight, is part of the Wadden Sea bordering the coastline of the south-eastern North Sea from the Netherlands up to Denmark. The bight is a closed basin situated between the mainland and the two islands, Sylt and Røm $\emptyset$, which are connected to the mainland by causeways (Fig. 1). There is only one connection to the North Sea through a deep tidal gully between the two islands. The whole area is $406 \mathrm{~km}^{2}$ in extent, including $135 \mathrm{~km}^{2}$ of tidal flats. The main intertidal area is occupied by sandflats. Dense Zostera beds cover $8 \%$ and sparse Zostera beds only $4 \%$ of the intertidal area. The coverage of the communities was measured by remote sensing (Murphy and Doerffer, personal communication) as well as by mapping (Reise and Lackschewitz 1998) directly on the tidal flats (Asmus H and Asmus R 1998).

Types of seagrass beds

Two seagrass species, Zostera marina L. and Zostera noltii Hornem., are found in intertidal parts of the Sylt-Rømø Bight. The

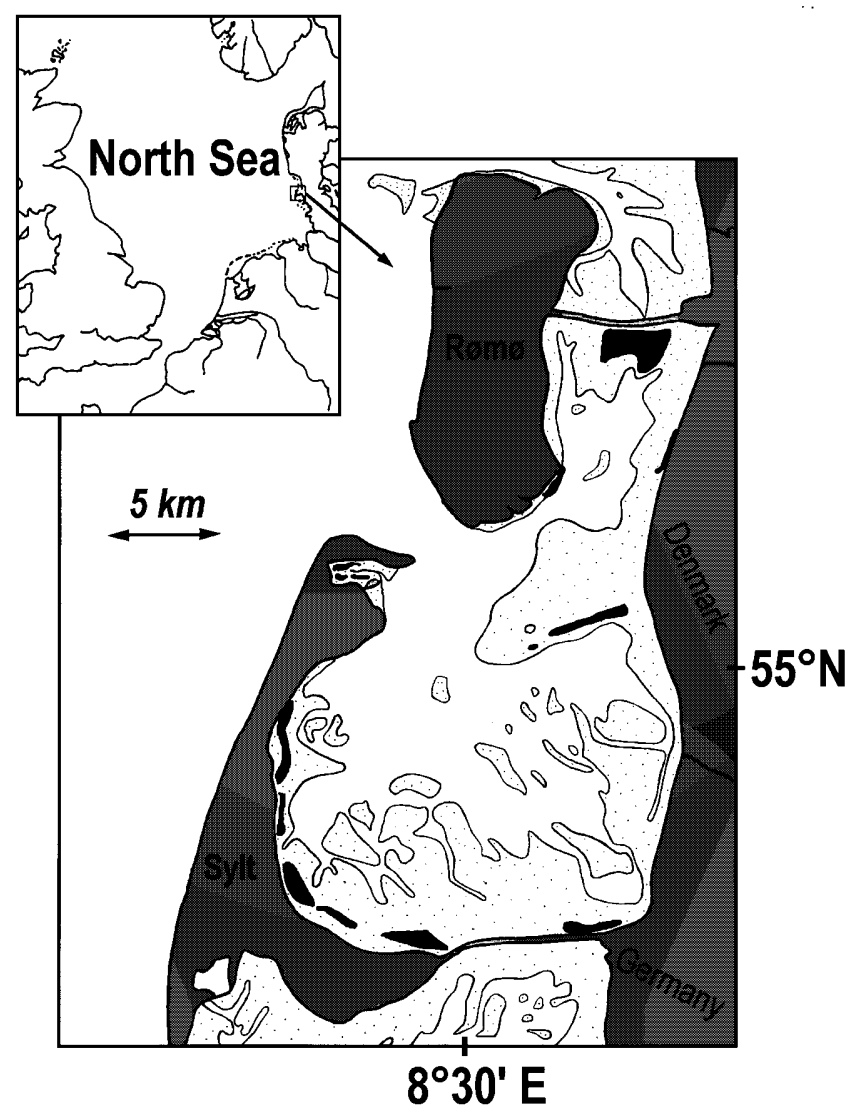

Fig. 1 Map of the Sylt-Rømø Bight, with distribution of seagrass beds 
subtidal form of Z. marina occurred until 1933 when the wasting disease reached the area (Wohlenberg 1935). This subtidal Z. marina was described as a perennial (Wohlenberg 1935). The intertidal form of $Z$. marina generally shows an annual life cycle at the investigation sites, but there is a great variability in the percentage of plants that develop every year from seedlings, growing to maximal biomass in August and September (Asmus R et al. 1998). In contrast with $Z$. marina, $Z$. noltii plants are perennial. They also lose their leaves in autumn, but they resist winter conditions by means of rhizomes remaining in the substrate.

A typical Z. marina meadow grows mainly in sheltered muddy substrates of the intertidal parts of the Sylt-Rømø Bight (or of the Wadden Sea) (Fig. 1). The bottom level in these areas is often slightly depressed, so that a thin water layer remains even during low water. In October seagrass plants are grazed to a large extent by brent geese (Branta bernicla) and wigeons (Anas penelope), but ungrazed plants lose their leaves until the end of October. In autumn and winter the sites of seagrass beds are bare mudflats with only a few scattered seagrasses.

$Z$. noltii beds also grow well in sheltered places. Pure Z. noltii stocks are rarely developed. In most years, $Z$. noltii and Z. marina form mixed stands. In sandy places only $Z$. noltii occurs. This type of a Zostera bed is more exposed to wind and waves than the dense type of seagrass bed.

\section{Sylt Flume}

The material exchange between seagrass beds and the overlying water was measured in a large flume (Fig. 2) in Z. marina beds in 1987 and 1991, and in a sparse Z. noltii bed in 1990. The flume technique has already been described (Asmus et al. 1994). One lane enclosed the natural seagrass bed, while in the other lane seagrasses were plucked off, so that the bare sediment was left. This lane served as a control. Every $30 \mathrm{~min}$, water samples were collected $15 \mathrm{~cm}$ above the bottom by electric pumps at the inflow of the flume, and a corresponding set of samples was taken when the water had passed the flume. The parameters measured were particulate organic $\mathrm{C}$, particulate organic $\mathrm{N}$, ammonium, nitrate, nitrite, total $\mathrm{N}$, total $\mathrm{P}$, dissolved inorganic $\mathrm{P}$, and dissolved silicate. The differences in concentration between inflow and outflow were used to estimate the material flux, considering the water volume passing in this time period. Current velocity was measured by drifting buoys as well as by induction current meters.

\section{Species diversity}

Species diversity was estimated in seagrass beds of the Sylt-Røm $\varnothing$ Bay during the period from 1980 to 1998 by analysing the lists of species of 12 published reports and publications and two unpublished summaries. The authors, references, seagrass types, faunal and floral groups investigated and the methods for obtaining species diversity data are summarised in Table 1.

Trophic transfer: biomass, productivity and consumption

Biomass values from Reise and Lackschewitz (1998) were used. Productivity was estimated from these biomass data using P:B ratios for the different species (Asmus H 1984; 1987). Consumption was estimated by adding respiration and production in $\mathrm{g} \mathrm{C}$ for the dominant species. Respiration was calculated using R:B-values (Asmus H 1984, 1994) for the particular species.

Table 1 References (including reports and doctoral theses) regarded for estimating faunal species diversity in intertidal seagrass beds of the Sylt-Rømø Bay

\begin{tabular}{llll}
\hline Group investigated & Community type & Observed year & Reference \\
\hline Macrofauna $(>500 \mu)$ & Z. noltii & 1980 & Asmus and Asmus 1985 \\
Parasites & of dominant macrofauna & $1980-1998$ & Lauckner (personal communication) \\
Turbellaria & Zostera beds & 1981 & Riebensahm 1981 \\
Mobile epifauna & Z. marina & 1988 & Hellwig-Armonies 1988 \\
Macrofauna $(>1 \mathrm{~mm})$ & Z. noltii & 1990 & Reise et al. 1994 \\
Macrofauna & Z. marina & 1991 & Blankenhorn 1992 \\
Macrofauna $(>1 \mathrm{~mm})$ & Z. noltii and Z. marina Beds & $1992-1994$ & Lackschewitz 1998 \\
Mobile epifauna & Z. noltii and Z. marina & 1993 & Gerbersdorf 1994 \\
Mobile epifauna & Z. noltii & 1995 & Schomburg 1997 \\
Endofauna $(>250 \mu)$ & Z. noltii & 1995 & Suhr 1996 \\
Macrofauna & Z. noltii & 1997 & Nacken 1998 \\
Macrofauna & Z. noltii and Z. marina & $1997-1999$ & Schanz (personal communication) \\
\hline
\end{tabular}

Fig. 2 Sylt Flume in Zostera beds (Photo: H. Asmus)

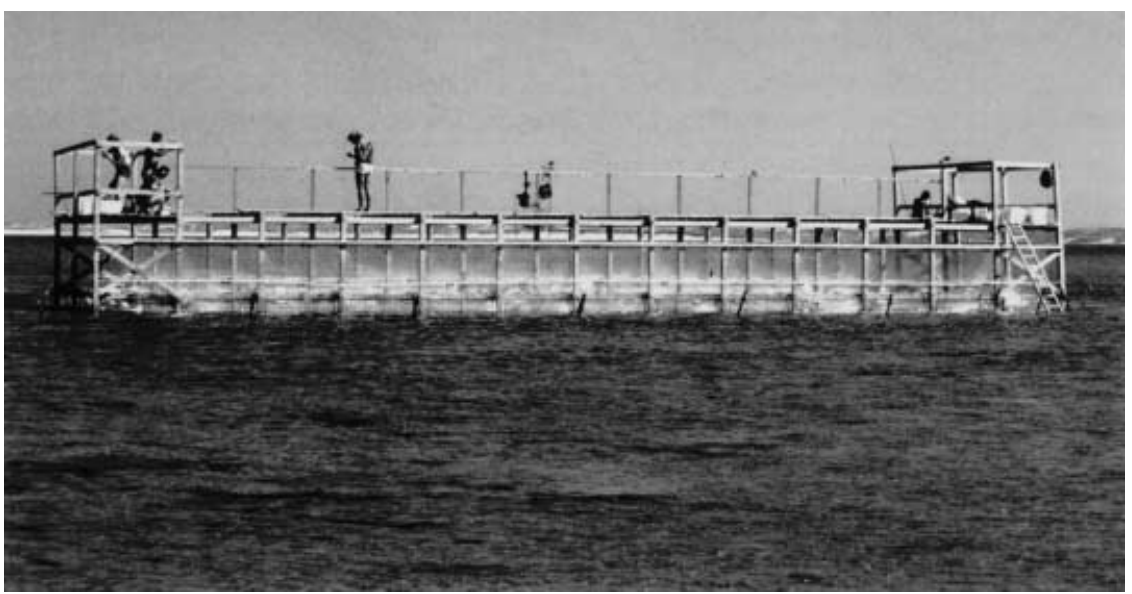




\section{Results}

Flume measurements

\section{Particulate organic $C$}

Particulate organic C (POC) was mainly imported into a dense intertidal Z. marina bed $(P<0.05)$ (Fig. 3). The muddy unvegetated control lane showed variable rates with an insignificant mean release of POC. The difference in POC flux between the vegetated and unvegetated flume lane was significant over whole tidal cycles (Mann Whitney U-test, $P<0.05 ; n=23)$. This difference became more distinct during an ebbing tide (same test, $P<0.005$, $n=11$ ) in that particles were held back in the seagrass bed while they were exported from the muddy sediment with increasing currents. The particle uptake was only evident in dense seagrass beds, whereas in sparse $Z$. noltii communities POC was released $(P<0.05)$ (Fig. 3). In sparse $Z$. noltii beds, the benthic-pelagic POC-exchange was not significantly different between vegetated and unvegetated flume lanes. The particle exchange between seagrass beds and the overlying water is strongly influenced by hydrodynamics (Fig. 4). The uptake of particles on calm days is only half the value of that on stormy days. Dense seagrass beds are situated in sheltered places of the Sylt-Rømø Bight, and these seagrass beds further diminish the currents and waves. Because the particle load of tidal waters increases during storms, the sedimentation rate between the seagrass leaves may also increase. In this way calm and stormy days may determine the direction and height of POC-fluxes. The stormy situation represents a wind of 6-8 Beaufort. This is the maximum wind speed at which experiments on the flume are possible.

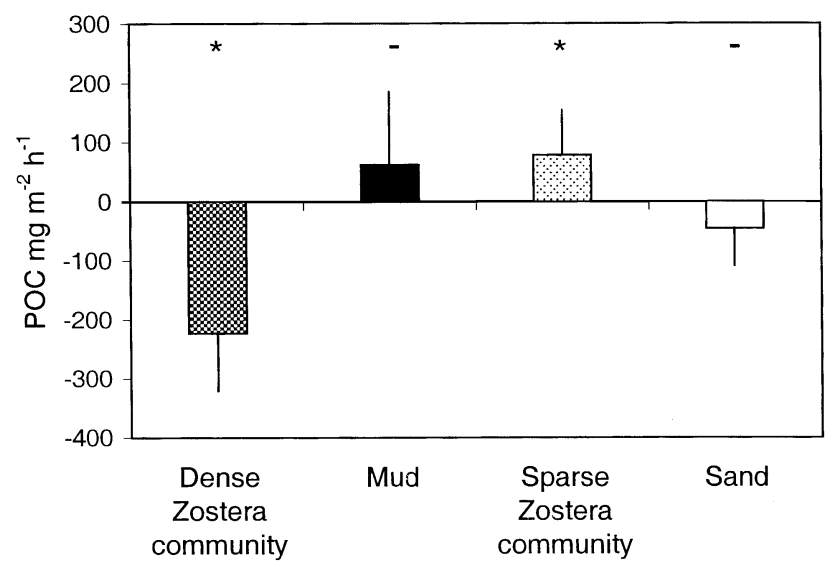

Fig. 3 Uptake (negative values) and release (positive rates) of particulate organic carbon (POC) in two dense seagrass beds, mainly Zostera marina (measured in 1987 and 1991), a muddy control lane (in 1991), and a sparse Zostera noltii bed with a sandy control lane (in 1990): * indicates that mean flux rates are significant over whole study periods (significance test Dixon and Mood, Mann Whitney U-test, $P<0.05$, Sachs 1983), whereas - indicates that fluxes are not significant over the whole study period

\section{$N$ measurements}

In dense seagrass beds dissolved inorganic $N$ (DIN) is significantly taken up $(P<0.05, n=36)$. There is a tendency for the uptake of particulate N (PN) and for a release of total $\mathrm{N}$ (TN), although this is not significant over the whole growing season (Fig. 5). Sparse seagrass beds release TN (significant, $P<0.05$ ) and PN (not significant) and take up only small amounts of DIN $(P<0.05)$. In both types of seagrass beds, only DIN is significantly different between vegetated and unvegetated areas (Mann-Whitney U-test, $P<0.05, Z$. noltii $n=50$, Z. marina $n=38)$.

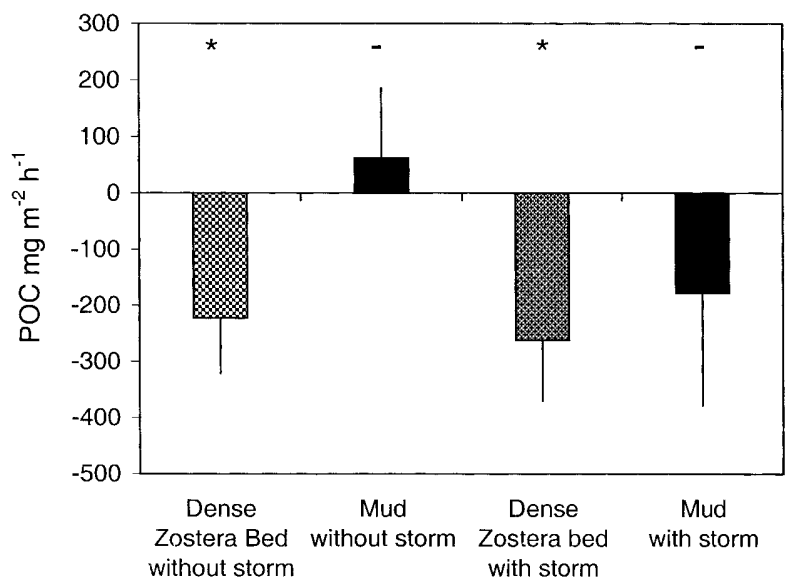

Fig. 4 Influence of storms on particle exchange (POC) in a Zostera marina bed. Uptake of particles is significant (*), while flux rates in the muddy control lane are not significant (-) (significance test Dixon and Mood, Mann Whitney U-test, $P<0.05$, Sachs 1983)

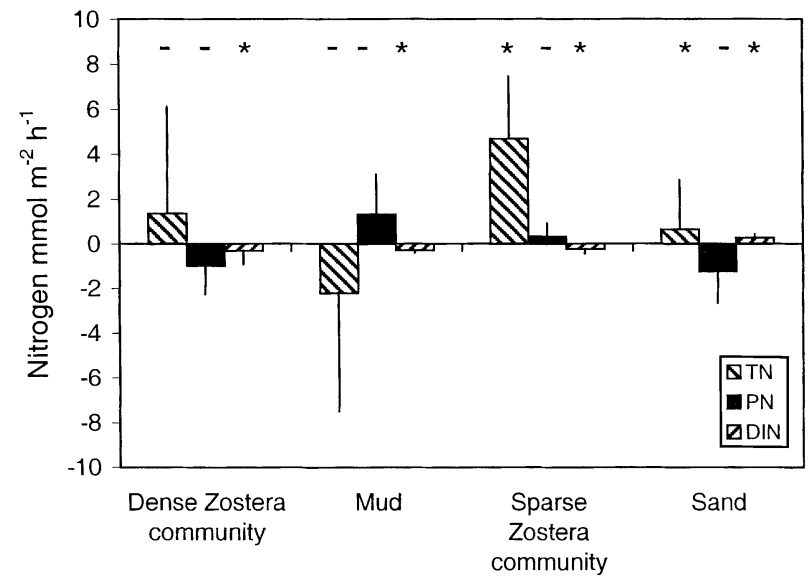

Fig. 5 Nitrogen dynamics in dense and sparse Zostera beds. Uptake of DIN (mainly ammonium) by seagrass meadows, in the muddy control lane and the ammonium release in the sandy lane are significant $(*)$. Release of particulate nitrogen from a sparse seagrass beds is also significant while other fluxes of PN and total nitrogen $(\mathrm{TN})$ over whole study periods are not significant $(-)$ (significance test Dixon and Mood, Mann Whitney U-test, $P<0.05$, Sachs 1983) 


\section{$P$ measurements}

The $\mathrm{P}$ compounds show a more regular pattern (Fig. 6). Dense Zostera beds were sinks for dissolved inorganic phosphate (DIP) and total P (TP). There was a significant difference between the TP uptake in the dense seagrass lane of the flume and the release of TP in the unvegetated muddy lane (Mann Whitney U-test, $P<0.01, n=23)$. The TP flux rates treated separately in the seagrass lane are not significant, while the TP rates in the muddy control are significant $(P<0.05)$. DIP was taken up $(P<0.05)$, but there was a significant difference between vegetated and unvegetated lanes only during ebbing tides (Mann Whitney U-test, $P<0.005$, $n=19)$. Sparse Zostera stocks release TP $(P<0.05)$ which could be explained by a release of DIP $(P<0.05)$. Neither the $\mathrm{P}$ flux rates in the sandy control lane nor the difference in TP and DIP exchange between vegetated and unvegetated lanes in the sparse $Z$. noltii bed were significant.

\section{Silicate}

Silicate was released in significant amounts by the muddy and sandy unvegetated flume lanes probably due to bioturbating infauna $(P<0.05)$ (Fig. 7). Also, in the sparse Z. noltii stand silicate was released, but this was not significant. There was a tendency for silicate uptake in the dense seagrass bed, although this was not significant over the whole growing season.

\section{Species diversity}

The species diversity of the investigated animal groups is comparatively rich (Fig. 8). Plant diversity in the intertidal seagrass beds of Königshafen is dominated by mi-

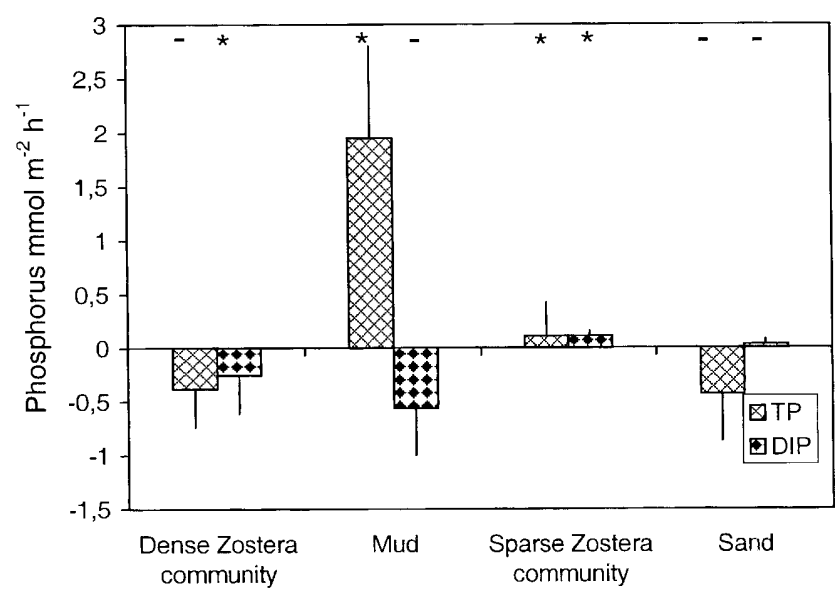

Fig. 6 Dissolved inorganic phosphate (DIP) was significantly (*) taken up by a dense seagrass bed, while it was released by a sparse seagrass bed (significance test Dixon and Mood, Mann Whitney U-test, $P<0.05$, Sachs 1983) crophytobenthos, with 70 species of diatoms and one species of blue-green algae, and in the total area 108 species of microalgae and one species of blue-green algae were reported (Asmus and Bauerfeind 1994). The diversity of macroalgae growing, for example, as epiphytes on seagrasses has not yet been quantitatively investigated in the seagrass beds of the Sylt-Røm ø Bight.

Biodiversity of the animal groups investigated in the intertidal seagrass beds of Sylt-Rømø Bay is high, representing $2-86 \%$ of the total number of species, depending on the particular group (Fig. 8). Among classes of animals, free living turbellarians dominate, with 435 species being found in Sylt-Rømø Bay (Reise 1988). However, only $12 \%$ of these meiobenthic species were reported from seagrass beds. Regarding macrofauna, polychaetes are reported to show the highest number of species (26 in seagrass beds, 38 in the total ecosystem). Among the Crustacea, only Malacostraca were included. The species number in this class would have been even higher if ostracodes and copepods had also been registered. Fish are also underestimated in this figure, because only those species which had been caught in ebb pools are shown. In addition, a number of fish species visit intertidal seagrass beds during the inundation period. The number of fish species in the total area is about 50 (Herrmann et al. 1998).

\section{Trophic transfer and energy flow}

In Fig. 9 a rough energy flow of the intertidal seagrass beds in the Sylt-Rømø Bight is presented. Only those values which could be measured by different research groups in the ecosystem research project (SWAP) working synchronously between 1990 and 1995 (Gätje and Reise 1998) are shown in this diagram. Primary production is represented by phytoplankton, microphytobenthos and Zostera plants. Phytoplankton primary production is

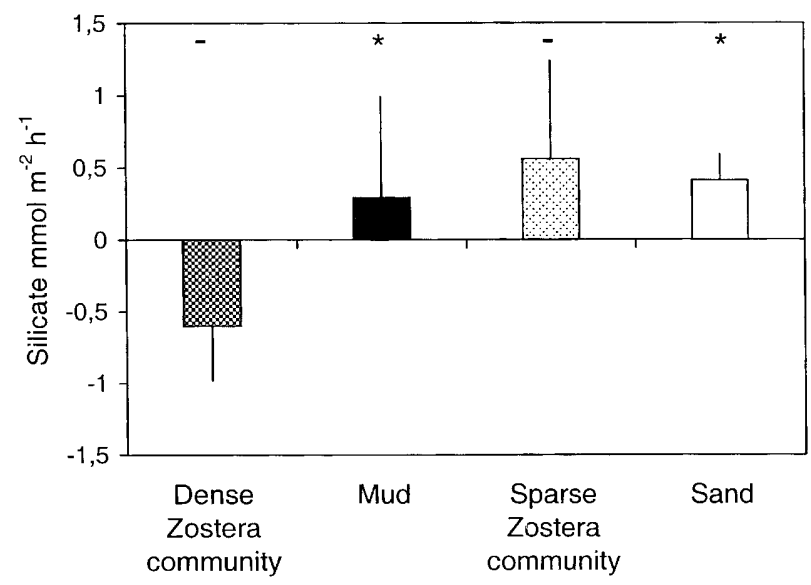

Fig. 7 Mud and sand released silicate in significant amounts (*), while flux rates in the seagrass beds were not significant over whole study periods (-) (significance test Dixon and Mood, Mann Whitney U-test, $P<0.05$, Sachs 1983) 
Fig. 8 Species numbers in seagrass beds of the Sylt-Røm $\varnothing$ Bay from different investigations from 1980 to 1998 (for references see Table 1)

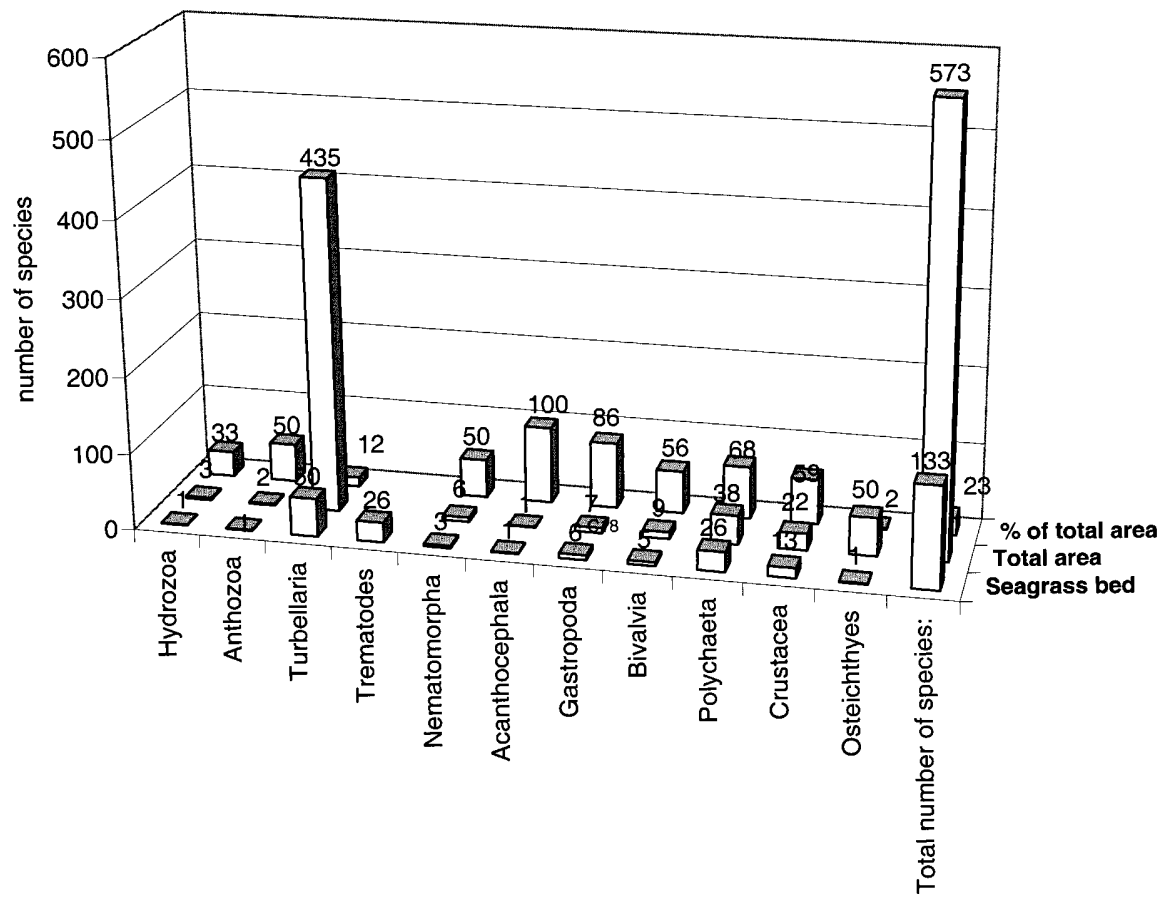

Energy Flow of a Seagrass Community in the Sylt-Römö Bight

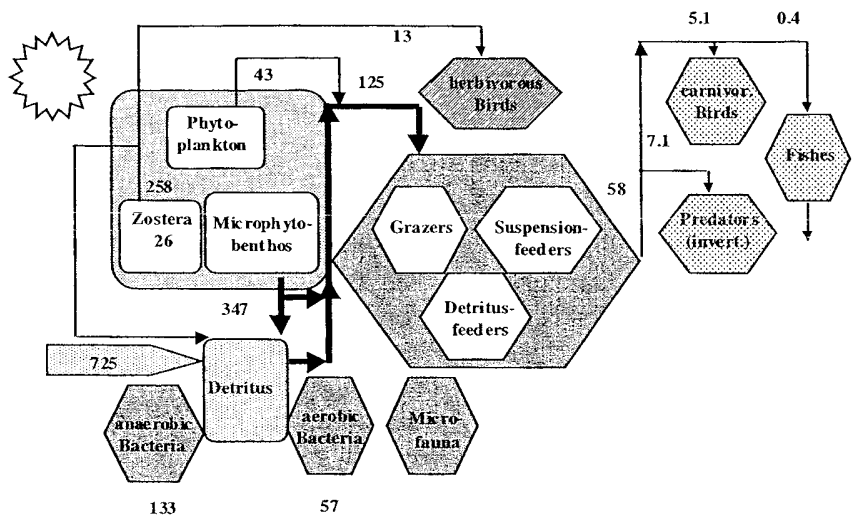

Fig. 9 Energy flow diagram (in $\mathrm{g} \mathrm{C} \mathrm{m}^{-2} \mathrm{a}^{-1}$ ) of a seagrass community in the Sylt-Rømø Bight

$43 \mathrm{~g} \mathrm{C} \mathrm{m}^{-2} \mathrm{a}^{-1}$, microphytobenthos produces up to $347 \mathrm{~g} \mathrm{C}^{-}$ $\mathrm{m}^{-2} \mathrm{a}^{-1}$, while Zostera produces $258 \mathrm{~g} \mathrm{C} \mathrm{m}^{-2} \mathrm{a}^{-1}$. Additionally, a detritus input of $725 \mathrm{~g} \mathrm{C} \mathrm{m}^{-2}$ is available as a potential primary energy source for the food web. About half $\left(13 \mathrm{~g} \mathrm{C} \mathrm{m}^{-2}\right)$ of the total $\mathrm{Z}$. biomass of $26 \mathrm{~g} \mathrm{C} \mathrm{m}^{-2}$ is used directly by herbivorous birds such as brent geese and wigeons. The phytoplankton, microphytobenthos and detritus are consumed by macrofauna with $125 \mathrm{~g} \mathrm{C}$ $\mathrm{m}^{-2} \mathrm{a}^{-1}$ coming from this source. $58 \mathrm{~g} \mathrm{C} \mathrm{m}^{-2} \mathrm{a}^{-1}$ is transported along the food web to higher trophic levels, especially invertebrate predators which consume $7.1 \mathrm{~g} \mathrm{C} \mathrm{m}^{-2}$ $\mathrm{a}^{-1}$. Carnivorous birds consume $5.1 \mathrm{~g} \mathrm{C} \mathrm{m}^{-2} \mathrm{a}^{-1}$, while fish consume $0.4 \mathrm{~g} \mathrm{C} \mathrm{m}^{-2} \mathrm{a}^{-1}$. Seals are at the end of this food chain.

\section{Discussion}

Material fluxes at a community level

Dense Zostera communities of the Sylt-Rømø Bay are effective sinks for particulate material, whereas sparse stocks react only slightly differently from bare intertidal sand bottoms. A sink function for autochthonous detritus was also suggested for $Z$. marina beds in a low current regime $\left(<53 \mathrm{~cm} \mathrm{~s}^{-1}\right)$ (Fonseca et al. 1983), which is comparable to the flow regime of the seagrass beds in this study. Using indirect measurements [e.g. isotopic dating of cored material (Boudouresque et al. 1980; Thommeret 1985) or lepidochronology (Pergent and Pergent-Martini 1990)], only sedimentation rates over longer periods are available. Direct measurements of particle fluxes in seagrass beds are rare. In Mediterranean Posidonia beds the retention capacity for particles was 15 times higher than in bare sediments (Gacia et al. 1999). The highest accumulation rates of suspended matter were found during the winter months (Dauby et al. 1995), since Posidonia leaves are developed throughout the year and the particle load is higher in winter than in summer. In the SyltRømø Bay, seagrass leaves are developed only during the vegetation period, and particle trapping could be measured only during this time. During the ebb tide, seagrass beds retained more suspended solids than unvegetated mudflats did, because resuspension of material is inhibited in seagrass beds (Bulthuis et al. 1984).

Dense seagrass beds are situated in sheltered parts of the Sylt-Røm $\varnothing$ Bight, and during the vegetation period they mediate hydrodynamic energy. In general, different types of seagrass beds have the potential to reduce currents and waves (Gambi et al. 1990; Fonseca and Calahan 1992; Worcester 1995). Because the particle 
load of the tidal water increases during storms by a factor of ten (Ward et al. 1984), the sedimentation rate between the seagrass leaves also increases. This phenomenon was also observed in Chesapeake Bay, where wave energy was attenuated by vegetation, suppressing resuspension and enhancing deposition (Ward et al. 1984). Probably at a higher wind speed than the 7 Beaufort measured in this study and a subsequent more intensive water movement, a dense seagrass bed may switch to being a particle source (Fonseca et al. 1983; Dauby et al. 1995; Koch 1999). Sparse seagrass beds are particle sources on calm days, because they are situated in very shallow and turbulent water. Unfortunately we do not have comparable measurements from stormy days in sparse seagrass beds. The difference between a stormy situation and a calm situation is obvious regarding the exchange pattern of the total intertidal ecosystem, which shows a high release during storms and a slight uptake during calm days (Asmus R and Asmus H 1998). Dense seagrass beds are therefore important sinks in the intertidal habitat, and they may play an important role as particle sinks at the ecosystem level.

Dense seagrass beds in the Sylt-Rømø Bay are significant sinks for DIN (Asmus et al. 1994), but show only a tendency to take up PN and to release TN. Sparse seagrass beds are sources for TN and PN and are only small sinks for DIN.

The source function for TN is surprising and the reason for this may be a significant release of dissolved organic $\mathrm{N}$ (DON) from seagrass beds, which exceeds the sink function for PN and DIN. Because the counteracting uptake of DIN is much higher in dense seagrass beds than in sparse seagrass beds, the net release of $\mathrm{TN}$ is higher in sparse seagrass beds. A three times higher TN content in the sediments of seagrass beds compared to bare mudflats was reported from tropical seagrass beds dominated by Syringodium isoetifolium (Ascherson) Dandy (Yamamuro et al. 1993). At the same site the DON content was found to be higher in the water within the seagrass canopy compared with other areas (Yamamuro et al. 1993). Earlier studies suggested an increase in bacterial activity in seagrass beds, probably due to the exudation of organic matter by seagrass roots and rhizomes during photosynthesis (Moriarty et al. 1986). The origin of the efflux probably from DON from seagrass beds is not clear, but these processes are definitely associated with the seagrass, because other communities do not show a DON efflux. This imbalance between the fluxes of the $\mathrm{N}$ compounds may be a consequence of an increased sedimentation of $\mathrm{N}$-containing particles following single irregular events (storms). This would keep the organic $\mathrm{N}$ pool in the sediment at a higher level, and intensify the remineralisation processes (indicated by a release of DON) and the bacterial activity for a longer time period. Hemminga et al. (1991) emphasised the role of such imbalances of net losses and net gains of nutrients for the fluctuations of seagrass productivity. This may be especially important in dynamic environments such as the Wadden Sea.
DIN was found to be low in water ebbing from seagrass beds as well as from mudflats (Bulthuis et al. 1984). Also, in the present study, the difference in DIN flux during ebb tide between mudflats and seagrass beds on mud showed a lower level of significance $(P<0.1)$ compared to the differences in $\mathrm{P}$ flux $(P<0.005)$. During the total tidal cycle, DIN differed significantly between vegetated and unvegetated areas. Seagrass communities are able to reduce ammonium concentrations (which contribute most to DIN in this study) in the water column considerably (Short and McRoy 1984; Short and Short 1984). They also intensify the turnover of the ammonium pool of sediments by a factor of 2-3 (Boon et al. 1986). This information from the literature as well as that from the comparison between the seagrass lane and the control lane of the flume suggests that a considerable amount of inorganic $\mathrm{N}$ remineralised within the seagrass bed and released by the sediments seems to be taken up by the seagrass leaves before an export out of the community occurs (Prieto and Corredor 1984; Hemminga et al. 1991; Asmus et al. 1994). DIN uptake in sparse seagrass beds is, therefore, smaller than in dense beds.

Dense Zostera beds were distinct sinks for TP and DIP, whereas sparse Zostera stocks release TP which could be explained by a release of DIP from the sediment. A sink function of seagrass beds for P compounds has been demonstrated by several authors. Bulthuis et al. (1984) showed that total and soluble reactive P concentrations did not increase significantly in water ebbing from intertidal seagrass beds, but increased by $30-100 \%$ in drainage from unvegetated flats. Also, in this study, a significant difference in DIP flux between vegetated (uptake) and unvegetated (release) lanes of the flume was only observed during ebbing. In the Sylt-Røm $\varnothing$ Bay, TP is dominated by soluble inorganic compounds, but also dissolved organic P (DOP) compounds are found to be important P sources for Zostera plants (Lapointe 1989; Tomasko and Lapointe 1991). This is made available by alkaline phosphatase activity (APA) found especially in leaves and probably also epiphytes of Posidonia oceanica and Cymodocea nodosa during low nutrient availability (Pérez and Romero 1993). In contrast, in Z. noltii APA was found to be independent of external concentrations (Hernández et al. 1994). The contribution of particulate organic P (POP) to TP uptake can be explained by the sink function for particles mentioned above.

Seagrass beds may depend on an import of POP, which enriches the interstitial water via remineralisation, especially during low phosphate concentrations in summer (Hemminga et al. 1991; Asmus et al. 1994). This remineralised $\mathrm{P}$ is rapidly taken up by the roots (PérezLloréns et al. 1993) and, therefore, $P$ concentrations in the interstitial water of seagrass beds were significantly lower than those in adjacent muddy sediments, where all vegetation had been experimentally removed (Asmus et al. 1994). The complex pattern of $P$ cycling within a seagrass bed is characterised by a dominance of DIP sinks such as roots and leaves of seagrass plants as well as benthic diatoms, epiphytes and associated macroalgae. 
At the ecosystem level, the storage of $\mathrm{P}$ in below-ground organs of seagrasses is estimated to shift $1-15 \%$ from the $\mathrm{P}$ input due to planktonic primary production to a large sink with low turnover (Romero et al. 1994). On the other hand, the role of seagrasses as a P pump from the sediment to the water is variable due to the relation of nutrient concentration in sediments to that of the water column. The translocation and leaching of $\mathrm{P}$ was found to be negligible in Z. marina and Z. noltii (Brix and Lyngby 1985; Pérez-Lloréns et al. 1993). There is some evidence that in temperate zones seagrass leaves take up a large amount of $\mathrm{P}$ from the surrounding water (Brix and Lyngby 1985), but the difference between vegetated and denuded sediments in this study showed that a large amount of the DIP taken up by seagrass beds was released directly by the sediments rather than imported by tidal water transport. This also explains the dominant release of DIP from sparse seagrass beds, which was consistent with the release of unvegetated sediments.

Dense Zostera stocks acted as sinks for silicate, but this was not significant over the whole growing season. This is explained by the occurrence of benthic and epiphytic diatoms, whereas seagrasses are probably not able to use silicate as a nutrient, because no stimulating effect for seagrass growth could be found in experiments where seagrasses were exposed to increasing silicate levels (Kamermans et al. 1999). In sparse seagrass beds as well as in unvegetated control areas of both seagrass types this effect is probably surpassed by the bioturbating infauna which significantly release silicate from the bottom to the water column (Asmus 1986). Bulthuis et al. (1984) found that both vegetated and unvegetated mudflats released silicate during ebb time. He explained this by an efflux of interstitial water. However, in bare mudflats the silicate level was significantly higher than in vegetated mudflats, possibly because the loss of seagrasses increases the efflux of interstitial water. On the other hand, a release of silicate from the bottom could be diminished by the uptake of epiphytic diatoms growing on the seagrass leaves.

\section{Material fluxes at the ecosystem level}

If we extrapolate the flux rates to the total area of the seagrass beds and compare this with the material exchange of the total intertidal region (Fig. 10a, b), it becomes evident that seagrass beds contribute a significant part to the material turnover of the total intertidal system, although seagrass beds cover only $12 \%$ of the intertidal area. The seagrass beds act as particle sinks in accordance with the total intertidal ecosystem, and they counteract the general trend of nutrient release on calm days (see Fig. 10a). The seagrass beds become nutrient sources if the stormy days are included in the material budget (see Fig. 10b). The coastal ecosystem, Banc d'Arguin, is dominated by seagrasses covering $84 \%$ of the intertidal area. Here a distinct sink effect for nutrients as well as particulate organic matter was observed for the total ecosystem (Wolff et al. 1993). Com-
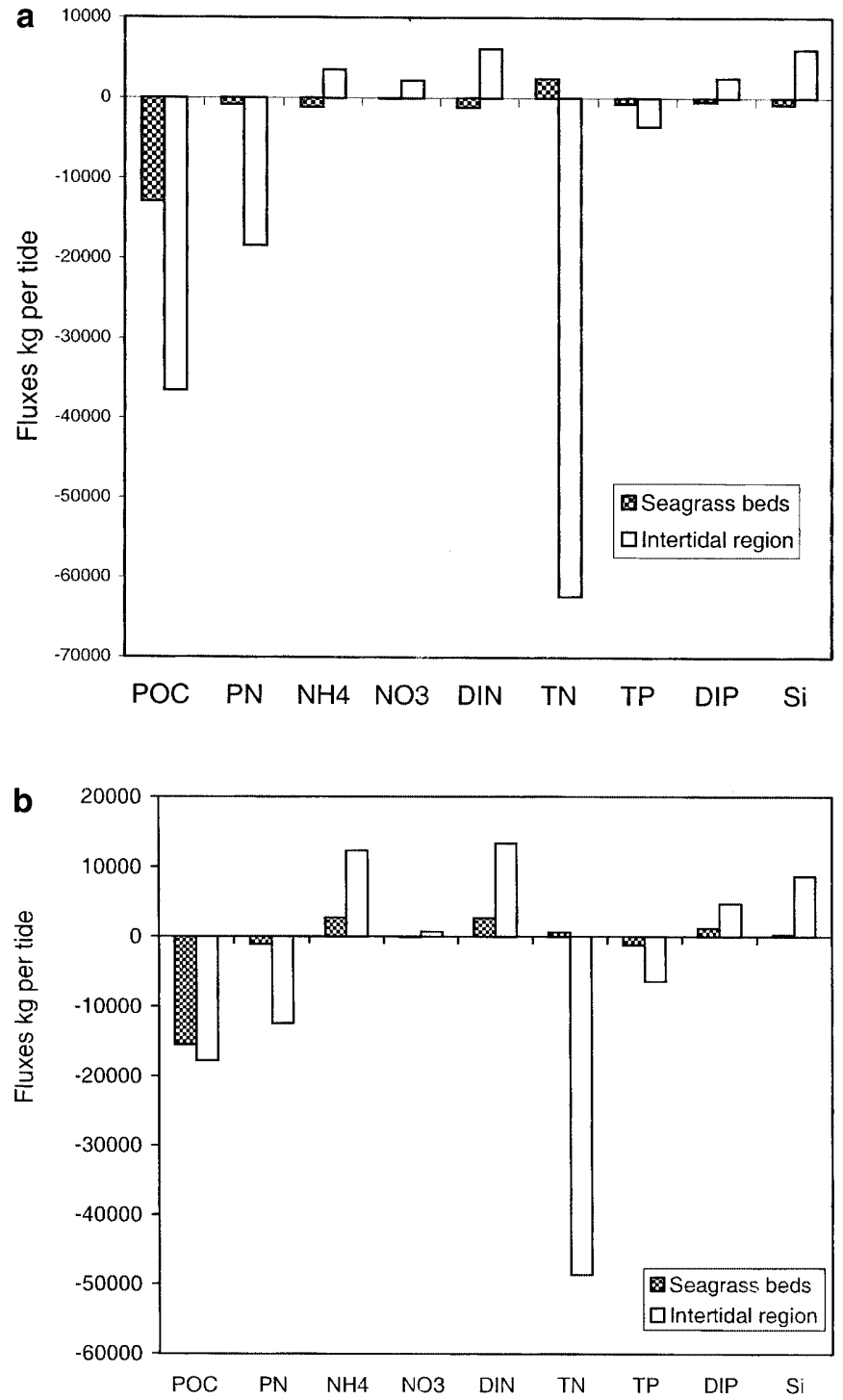

Fig. 10 Material turnover in $\mathrm{kg}$ per tide and total area of intertidal seagrass beds in the Sylt-Røm $\varnothing$ Bight $\left(16 \mathrm{~km}^{2}\right)$ (chequered columns) compared with the the material turnover of the total intertidal region of the bay $\left(135 \mathrm{~km}^{2}\right)$ (white columns) and either without stormy situations (a) or with storms included (b)

parisons between benthic oxygen sulphide and nutrient fluxes of different macrophyte communities reveal that $Z$. noltii communities in Arcachon Bay had a stabilising effect on the benthic fluxes (Viaroli et al. 1996). Even these few studies show that the function of the ecosystem either as a source or a sink is influenced by the percentage cover of seagrass beds. In the present study, the seagrass cover was not high enough to control the direction of the ecosystem function, but it contributed significantly to the material budget and determined the material exchange rates.

\section{Exclusion of seagrass beds}

What would happen to the material flux of the intertidal area of the Sylt-Rømø Bay if all seagrass beds became 


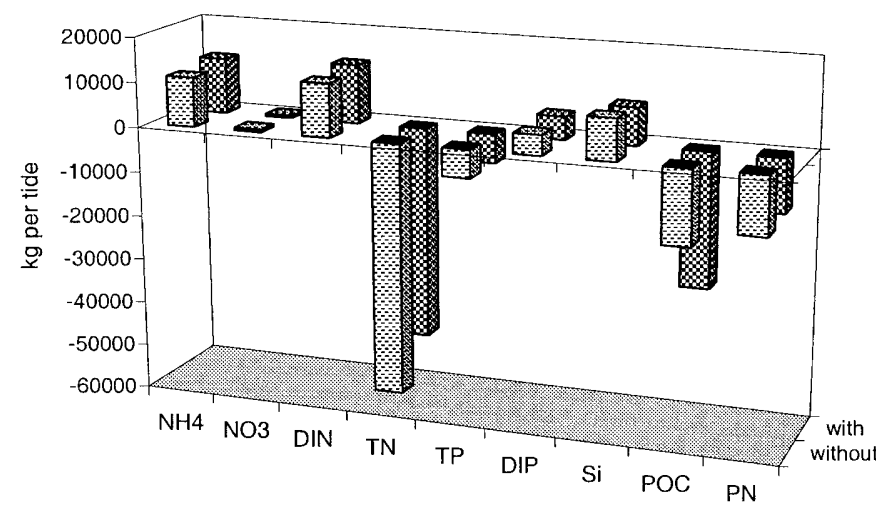

Fig. 11 Material turnover ( $\mathrm{kg}$ per tide) of the total intertidal area of the Sylt-Rømø Bight with seagrass beds (dark chequered columns) and without, i.e. when seagrass beds were substituted by Arenicola - sandflats (light chequered columns)

extinct or disappeared. This scenario is illustrated in Fig. 11, where seagrass beds were replaced by Arenicola sandflats to simulate the loss of seagrass beds. This leads to two relevant alterations in the material budget at the ecosystem level: (1) the POC uptake is dramatically reduced if seagrass beds are absent and (2) the uptake of $\mathrm{TN}$ by the system increases. A dominant role of seagrass beds for intensifying organic matter exchange and bacterial production at ecosystem level was also observed by Middelboe et al. (1998) in Limfjorden. These fundamental alterations may have serious consequences for the ecosystem, because they may influence the further development and this may also have implications for the energy flow and the food web of the system.
If we exclude seagrass beds from the system, firstly the $\mathrm{C}$ or energy flow will show some important alterations. One important consequence is that the detritus input per year to the total system will be reduced by $32 \%$ of the value we find in intertidal areas with seagrass beds. This may well have fundamental consequences for the whole ecosystem (Table 2), because the loss of seagrass beds may reduce the benthic deposition of organic matter and at the same time may increase material turnover in the water column.

Other important components of the ecosystem would also be affected if seagrasses were lost. The aerobic microbial turnover would be reduced by $9 \%$, while the anaerobic microbial turnover would be reduced by $7 \%$. The importance of detritus import for bacterial activity in seagrass beds has been reported from different areas by several authors (Pollard and Kogure 1993; Yamamuro et al. 1993; Middelboe et al. 1998).

Seagrass beds in the present study have a high species richness but most species found in these intertidal seagrass beds are not specific to this community, but also occur in adjacent areas without macrobenthic vegetation (den Hartog 1983). Exceptions are the isopods Idothea balthica and I. chelipes, as well as the hydrozoon Orthopyxis integra (Reise and Lackschewitz 1998). The secondary production and biomass of macrofauna shows a value similar to the average of the total bight; but consumption in seagrass beds is slightly higher.

Therefore, if seagrass beds are excluded from the system, the sum of macrofaunal consumption may decrease slightly (by 1\%), whereas secondary production seems to be less affected. This is in contradiction to other studies showing eelgrass beds to make a major contri-

Table 2 Alterations of ecological features after theoretical exclusion of seagrass beds: production, biomass and consumption at different trophic levels $\left(\mathrm{g} \mathrm{C} \mathrm{m}^{-2} \mathrm{a}^{-1}\right)$ in the intertidal Sylt-Rømø Bay in the period 1990-1995

\begin{tabular}{|c|c|c|c|c|}
\hline & With seagrass beds & Without seagrass & $\%$ Change & Reference \\
\hline \multicolumn{5}{|l|}{ Primary production and detritus input } \\
\hline Phytoplankton primary production & 43 & 43 & 0 & Asmus $\mathrm{H}$ et al. 1998 \\
\hline Microbenthic primary production & 357 & 356 & 0 & Asmus $\mathrm{H}$ et al. 1998 \\
\hline Seagrass gross primary production & 30 & 0 & -100 & Asmus $\mathrm{H}$ et al. 1998 \\
\hline Seagrass biomass & 3 & 0 & -100 & Asmus H et al. 1998 \\
\hline Detritus input & 226 & 154 & -32 & Asmus H and Asmus R 1998 \\
\hline Total & 659 & 553 & & \\
\hline \multicolumn{5}{|l|}{ Small food web and microbial turnover } \\
\hline Aerobic microbial metabolism & 40 & 37 & -9 & Kristensen et al. 1998 \\
\hline Unaerobic microbial metabolism & 94 & 88 & -7 & Kristensen et al. 1998 \\
\hline \multicolumn{5}{|l|}{ Macrobenthic secondary production } \\
\hline Consumption (net) & 98 & 97 & -1 & \\
\hline Biomass & 29 & 28 & -1 & Reise and Lackschewitz 1998 \\
\hline Production & 54 & 54 & 0 & \\
\hline \multicolumn{5}{|l|}{ Predatory macrobenthos } \\
\hline Shore crabs & 0.4 & 0.1 & -71 & \\
\hline Infaunal predators & 4 & 4 & 0 & \\
\hline \multicolumn{5}{|l|}{ Birds (consumption) } \\
\hline Carnivorous birds & 5.05 & 5.05 & 0 & Scheiffarth and Nehls 1997 \\
\hline Herbivorous birds & 1.8 & 0 & -100 & Madsen 1988 \\
\hline
\end{tabular}


bution to species richness (Orth et al. 1984; Zieman and Zieman 1989) and secondary production in shallow water communities (Baden and Pihl 1984; Fredette et al. 1990; Kalejta and Hockey 1991; Valentine and Heck 1993; Heck et al. 1995). The reason for this is that the former authors mainly described subtidal seagrass beds, where the second trophic step is enhanced and there are also many seagrass residents. This is also reported from early studies in the Sylt-Røm $\varnothing$ Bight, where subtidal seagrass beds occurred before 1933 (Wohlenberg 1935). In the intertidal area of the Sylt-Røm $\varnothing$ Bight, secondary production shows the following ranking at the community level:

\section{mussel beds $>$ muddy sands $>$ seagrass beds $>$ sandflats $>$ mudflats $>$ sandy shoals}

(Asmus 1987; Asmus R et al. 1998).

These small alterations at the consumer level of the ecosystem mask distinct qualitative alterations within the dominance of trophic guilds. The average biomass of benthic grazers such as the mud snails Hydrobia ulvae and Littorina littorea in the system is reduced to around $30 \%$ when seagrass beds are absent. With respect to biomass and secondary production of benthic grazers, the intertidal communities are ranked as follows:

\section{seagrass beds $>$ mussel beds $>$ mudflats}

$>$ muddy sands $>$ sandflats $>$ sandy shoals.

The dominance of benthic grazers in seagrass beds was found to be related to the epiphyte availability (Bologna and Heck 1999). Therefore, in intertidal Zostera beds (this study) and Posidonia beds, this group surpassed other trophic guilds in shallow seagrass associations compared with deeper ones (Gambi et al. 1992).

The reduction was not significant in other trophic guilds of the macrofauna such as suspension-feeders, detritus feeders and various other feeding types as far as they were permanently present. We do not yet have any information on the mobile epibenthos in intertidal seagrass beds of the study area. This group will be important because, as many authors have shown, this group prefers vegetation as a habitat (Edgar and Robertson 1992; Connolly 1994a, c, 1997). Therefore, changes for this group are probable.

In the higher trophic levels, there are no apparent differences in infaunal predators, but predation by shore crabs (Carcinus maenas) changed dramatically. A high degree of crab predation was also reported for eelgrass beds worldwide (e.g. Strieb et al. 1995). It is evident that herbivorous birds, which are the predominant direct grazers on seagrasses in the Wadden Sea (Madsen 1988), would not find food on the tidal flats if seagrass beds were missing; therefore a $100 \%$ decrease is assumed.

\section{Historical changes}

The seagrass beds we recently found in the Sylt-Røm $\varnothing$ tidal areas seem to be only relicts from a time when seagrass beds were more important to the ecosystem than today. There is evidence for the Königshafen, that former intertidal beds were different in size and distribution than the present ones (Nienburg 1927; Reise et al. 1989). In the 1930s (1932-1936) these seagrass beds were damaged by the parasitic slime mould Labyrinthula, which caused the wasting phenomenon (Wohlenberg 1935; den Hartog, 1987). In concert with unfavourable environmental conditions (e.g. increasing eutrophication, turbidity and erosion of areas in a suitable depth for seagrass growth), the subtidal stocks of seagrasses did not recover until recently. The loss of subtidal seagrasses must have led to dramatic changes in the ecosystem. In contrast to the intertidal seagrass beds, subtidal seagrass beds have a rich and specialised fauna (Orth et al. 1984; Zieman and Zieman 1989), and a loss of this community may have had a stronger impact on species diversity of the total system compared to a possible loss of intertidal seagrass beds. The loss of spawning grounds for herring Clupea harengus (Wohlenberg 1935) and the loss of sea sticklebacks Spinachia spinachia and the deep-snouted pipefish Siphonostoma typhle are only a few examples of losses reported from the Wadden Sea area.

In the tidal gullies the dense mat of rhizomes within the sediment may have counteracted erosion and, therefore, immediately after the loss of only one subtidal seagrass bed (about 80 ha) in Königshafen at least 40,000 $\mathrm{m}^{3}$ of sediments were eroded (Wohlenberg 1935). Because of the important role seagrasses play in the material budget of the ambient ecosystem, it is possible to formulate the hypothesis that in historical times the loss of seagrasses may have led to fundamental changes in the material budget and has probably promoted the erosion of sediments in the whole of the Wadden Sea (Jespersen and Rasmussen 1994).

In the shallowest part of the subtidal area of the SyltRøm $\varnothing$ Bight from low spring tide line to $5 \mathrm{~m}$ depth, changes of water volume show an increasing trend. This means that the shallow subtidal part has been extended over the last 100 years with a concomitant decline of the area (Higelke 1998). In the parts deeper than $5 \mathrm{~m}$ below low spring tide level, there is no significant trend. The period with low water volumes in the shallow subtidal areas (from 1879 to 1935) can be distinguished from the period after 1950 with high water volumes. In the period 1935-1950, a dramatic increase in water volumes was observed, which may indicate that in this time period a large amount of sediments has been eroded and tidal flats have probably been lost. This period is also characterised by substantial changes in the ecosystem (Reise 1982, 1998; Riesen and Reise 1982; Reise et al. 1989; Asmus H and Asmus R 1998). The hypothesis of a causal connection between the loss of seagrass beds and an increasing water volume in the tidal gullies due to erosion could not be verified or disproved until now. How- 
ever, other possible causes of erosion in the Sylt-Rømø Bay may be the construction of the causeways from the mainland to the islands or the documented increase in tidal range.

\section{Conclusions}

Intertidal communities of the Sylt-Rømø Bight act as a particle sink and a nutrient source. Seagrass beds play a major role as important particle sinks which are significant also at the ecosystem level. The extinction of seagrass beds will lead to changes in the material budget of the total ecosystem. It will additionally affect the food web. The loss of subtidal seagrass beds in the past may have been accompanied by fundamental changes in the material budget of the total system and may have promoted erosion of the shallow subtidal areas. Historical changes in macrobenthic communities of the Sylt-Røm $\varnothing$ Bight are correlated with changing water masses and building activities, but it is not known whether there is a causal connection. The example of the history of seagrass beds in the Wadden Sea may show that changes in single communities may have induced changes which are visible at the ecosystem level. It also illustrates that we urgently need further large-scale ecosystem analyses combined with thorough historical research in order to understand the fate of our coastal ecosystems.

Acknowledgements Inestimable technical help was offered by J. Berger in the field as well as in the laboratory. We are very grateful to B. Ipsen for his efficacious help in constructing the Sylt Flume. We also thank all the students who were involved in obtaining these measurements, for their commitment when getting wet and muddy during the field campaigns and for their patience sitting at high tide on the flume for hours during night and day, storm and rain. This study is a publication of the Alfred Wegener Institute, no: 1748 .

\section{References}

Agawin NSR, Duarte CM, Fortes MD (1996) Nutrient limitation of Philippine seagrasses (Cape Bolinao, NW Philippines): in situ experimental evidence. Mar Ecol Prog Ser 138:233-243

Alcoverro T, Romero J, Duarte CM, López NI (1997) Spatial and temporal variations in nutrient limitation of seagrass Posidonia oceanica growth in the NW Mediterranean. Mar Ecol Prog Ser 146:155-161

Asmus H (1984) Freilanduntersuchungen zur Sekundärproduktion und Respiration benthischer Gemeinschaften im Wattenmeer der Nordsee. Ber Inst Meereskd Kiel 122, pp 1-171

Asmus H (1987) Secondary production of an intertidal mussel bed community related to its storage and turnover compartments. Mar Ecol Prog Ser 39:251-266

Asmus H (1994) Benthic grazers and suspension feeders: which one assumes the energetic dominance in Königshafen? Helgol Meeresunters 48:217-231

Asmus H, Asmus R (1985) The importance of grazing food chain for energy flow and production in three intertidal sand bottom communities of the northern Wadden Sea. Helgol Meeresunters 39:273-301

Asmus H, Asmus R (1998) The role of macrobenthic communities for the sediment-water material exchange in the Sylt -Røm $\varnothing$ tidal basin. Senckenberg Marit 29:111-119
Asmus H, Lackschewitz D, Asmus R, Scheiffarth G, Nehls G, Herrmann J-P (1998) Transporte im Nahrungsnetz eulitoraler Wattflächen der Sylt-Rømø Bucht. In: Gätje C, Reise K (eds) Ökosystem Wattenmeer, Austausch-, Transport- und Stoffumwandlungsprozesse. Springer, Berlin Heidelberg New York, pp 393-420

Asmus R (1986) Nutrient flux in short-term enclosures of intertidal sand communities. Ophelia 26:1-18

Asmus R, Asmus H (1998) Bedeutung der Organismengemeinschaften für den bentho-pelagischen Stoffaustausch im SyltRømø Wattenmeer. In: Gätje Ch, Reise K (eds) Ökosystem Wattenmeer Austausch-, Transport- und Stoffumwandlungsprozesse. Springer, Berlin Heidelberg New York, pp 257-302

Asmus R, Bauerfeind E (1994) The microphytobenthos - spatial and seasonal distribution on a sandy tidal flat. Helgol Meeresunters 48:257-276

Asmus RM, Asmus H, Wille A, Francés Zubillaga G, Reise K (1994) Complementary oxygen and nutrient fluxes in seagrass beds and mussel banks? In: Dyer KR, Orth RJ (eds) Changes in fluxes in estuaries: implications from science to management. Olsen and Olsen, Fredensborg, pp 227-237

Asmus RM, Jensen MH, Murphy D, Doerffer R (1998) Primärproduktion von Mikrophytobenthos, Phytoplankton und jährlicher Biomasseertrag des Makrophytobenthos im SyltRømø Wattenmeer. In: Gätje C, Reise K (eds) Ökosystem Wattenmeer, Austausch-, Transport- und Stoffumwandlungsprozesse. Springer, Berlin Heidelberg New York, pp 367-392

Baden S, Pihl L (1984) Abundance, biomass and production of mobile epibenthic fauna in Zostera marina (L.) meadows, western Sweden. Ophelia 23:65-90

Bell JD, Ferrell DJ, McNeill SE, Worthington DG (1992) Variation in assemblages of fish associated with deep and shallow margins of the seagrass Posidonia australis. Mar Biol 114: $667-676$

Blankenhorn D (1992) Einfluß von Seegrasbewuchs auf die Makrofauna schlickiger und sandiger Wattböden. Diplomarbeit im Institut für Zoologie der freien Universität Berlin, pp 1-80

Bologna PAX, Heck KL Jr (1999) Macrofaunal associations with seagrass epiphytes: relative importance of trophic and structural characteristics J Exp Mar Biol Ecol 242:21-39

Boon PI, Moriaty DJW, Saffigna PG (1986) Rates of ammonium turnover and the role of amino-acid deamination in seagrass (Zostera capricorni) beds of Moreton Bay, Australia. Mar Biol 91:259-268

Borg A, Pihl L (1997) Habitat choice by juvenile cod (Gadus morhua L.) on sandy bottoms with different vegetation types. Helgol Meeresunters 51:197-212

Boudouresque CF, Thommeret J, Thommeret Y (1980) Sur la découverte d'un bioconcrétionnement fossile intercalé dans l'herbier à Posidonia oceanica dans la baie de Calvi (Corse). J Syst Biogeogr Médit Cagliari:139-142

Brix H, Lyngby JE (1985) Uptake and translocation of phosphorus in eelgrass (Zostera marina). Mar Biol 90:111-116

Buia MC, Zupo V, Mazzella L (1992) Primary production and growth dynamics in Posidonia oceanica. Mar Ecol 13:2-16

Bulthuis DA, Brand GW, Mobley MC (1984) Suspended sediments and nutrients in water ebbing from seagrass-covered and denuded tidal mudflats in a southern Australian embayment. Aquat Bot 20:257-266

Burkholder JM, Mason KM, Glasgow HB Jr (1992) Water-column nitrate enrichment promotes decline of eelgrass Zostera marina: evidence from seasonal mesocosm experiments. Mar Ecol Prog Ser 81:163-178

Caffrey JM, Kemp WM (1990) Nitrogen cycling in sediments with estuarine populations of Potamogeton perfoliatus and Zostera marina. Mar Ecol Prog Ser 66:147-160

Caffrey JM, Kemp WM (1992) Influence of the submersed plant, Potamogeton perfoliatus, on nitrogen cycling in estuarine sediments. Limnol Oceanogr 37:1483-1495

Connolly RM (1994a) Removal of seagrass canopy: effects on small fish and their prey. J Exp Mar Biol Ecol 184:99-110 
Connolly RM (1994b) A comparison of fish assemblages from seagrass and unvegetated areas of a southern Australian estuary. Aust J Mar Freshwater Res 45: 1033-1044

Connolly RM (1994c) The role of seagrass as preferred habitat for juvenile Sillaginodes punctata (Cuv. \& Val.) (Sillaginidae, Pisces): habitat selection or feeding? J Exp Mar Biol Ecol 180: 39-47

Connolly RM (1997) Differences in composition of small, motile invertebrate assemblages from seagrass and unvegetated habitats in a southern Australian estuary. Hydrobiologia 346:137-148

Dauby P, Bale AJ, Bloomer N, Canon C, Ling RD, Norro A, Robertson JE, Simon A, Théate JM, Watson AJ, Frankignoulle M (1995) Particle fluxes over a Mediterranean seagrass bed: a one year case study. Mar Ecol Prog Ser 126:233-246

Duarte CM, Hemminga MA, Marbá N (1996) Growth and population dynamics of Thallassodendron ciliatum in a Kenyan back-reef lagoon. Aquat Bot 55:1-11

Durako MJ (1994) Seagrass die-off in Florida Bay (USA): changes in shoot demographic characteristics and population dynamics in Thalassia testudinum. Mar Ecol Prog Ser 110:59-66

Edgar GJ, Robertson AI (1992) The influence of seagrass structure on the distribution and abundance of mobile epifauna: pattern and process in a Western Australian Amphibolis bed. J Exp Mar Biol Ecol 160:13-31

Edgar GJ, Shaw C (1995a) The production and trophic ecology of shallow-water fish assemblages in southern Australia .I. Species richness, size structure and production of fishes in Western Port, Victoria. J Exp Mar Biol Ecol 194:53-81

Edgar GJ, Shaw C (1995b) The production and trophic ecology of shallow-water fish assemblages in southern Australia .III. General relationships between sediments, seagrasses, invertebrates and fishes. J Exp Mar Biol Ecol 194:107-131

Erftemeijer PLA, Middelburg JJ (1995) Mass balance constraints on nutrient cycling in tropical seagrass beds. Aquat Bot 50: 21-36

Ferrell DJ, McNeill SE, Worthington DG, Bell JD (1993) Temporal and spatial variation in the abundance of fish associated with the seagrass Posidonia australis in south-eastern Australia. Aust J Mar Freshwater Res 44:881-899

Fonseca MS (1989) Sediment stabilization by Halophila decipiens in comparison to other seagrasses. Estuar Coast Shelf Sci 29:501-507

Fonseca MS, Calahan JA (1992) Preliminary evaluation of wave attenuation by four species of seagrass. Estuar Coast Shelf Sci $35: 565-576$

Fonseca MS, Fisher JS (1986) A comparison of canopy friction and sediment movement between four species of seagrass with reference to their ecology and restoration. Mar Ecol Prog Ser 29:15-22

Fonseca MS, Zieman JC, Thayer GW, Fisher JS (1983) The role of current velocity in structuring seagrass meadows. Estuar Coast Shelf Sci 17:367-364

Fourqurean JW, Zieman JC, Powell GVN (1992) Phosphorus limitation of primary production in Florida Bay: Evidence from C: $\mathrm{N}$ : $\mathrm{P}$ ratios of the dominant seagrass Thalassia testudinum. Limnol Oceanogr 37:162-171

Francour P (1997) Fish assemblages of Posidonia oceanica beds at Port-Cros (France, NW Mediterranean): assessment of composition and long-term fluctuations by visual census. PSZN: Mar Ecol 18: 157-173

Fredette TJR, Diaz RJ, Montfrans J van, Orth RJ (1990) Secondary production within a seagrass bed (Zostera marina and Ruppia maritima) in lower Chesapeake Bay. Estuaries 13:431-440

Gacia E, Granata TC, Duarte CM (1999) An approach to measurement of particle flux and sediment retention within seagrass (Posidonia oceanica) meadows. Aquat Bot 65:255-268

Gambi MC, Nowell ARM, Jumars PA (1990) Flume observations on flow dynamics in Zostera marina (eelgrass) beds. Mar Ecol Prog Ser 61:159-169

Gambi MC, Lorenti M, Russo GF, Scipione MB (1992) Depth and seasonal distribution of some groups of the vagile fauna of the Posidonia oceanica leaf stratum: structural and trophic analyses. Mar Ecol 13:17-39
Gätje Ch, Reise K (eds) (1998) Ökosystem Wattenmeer, Austausch-, Transport- und Stoffumwandlungsprozesse. Springer, Berlin Heidelberg New York

Gerbersdorf S (1994) Epifauna in eulitoralen Seegraswiesen des Sylter Wattenmeeres. Diplomarbeit der Ruprecht-Karls-Universität Heidelberg, pp 1-85

Giesen WBJT, Katwijk MM, Hartog C den (1990) Temperature, salinity, insolation and wasting disease of eelgrass (Zostera marina L.) in the Dutch Wadden Sea in the 1930s. Neth J Sea Res 25:395-404

Halliday IA (1995) Influence of natural fluctuations in seagrass cover on commercial prawn nursery grounds in a subtropical estuary. Mar Freshwater Res 46:1121-1126

Hartog C den (1970) The sea-grasses of the world. Verhandlingen der Koninklijke Nederlandse Akademie van Wetenschappen Afd. Natuurkunde Tweede Reeks Deel 59 No. 1. North-Holland, Amsterdam

Hartog C den (1983) Structural uniformity and diversity in Zostera-dominated communities in western Europe. Mar Technol Soc J 17:6-14

Hartog C den (1987) "Wasting disease" and other phenomena in Zostera beds. Aquat Bot 27:3-14

Hartog C den, Polderman PJG (1975) Changes in the seagrass populations of the Dutch Waddenzee. Aquat Bot 1:141-147

Heck KL Jr, Able KW, Roman CT, Fahay MP (1995) Composition, abundance, biomass, and production of macrofauna in a New England estuary: comparisons among eelgrass meadows and other nursery habitats. Estuaries 18:379-389

Hellwig-Armonies M (1988) Mobile epifauna on Zostera marina, and infauna of its inflorescences. Helgol Meeresunters 42: 329-337

Hemminga MA, Harrison PG, Lent F van (1991) The balance of nutrient losses and gains in seagrass meadows. Mar Ecol Prog Ser 71:85-96

Hemminga MA, Koutstaal BP, Soelen J van, Merks AGA (1994) The nitrogen supply to intertidal eelgrass (Zostera marina). Mar Biol 118:223-227

Hernández I, Pérez-Llorens JL, Fernández JA, Niell FX (1994) Alkaline phosphatase activity in Zostera noltii Hornem. and its contribution to the release of phosphate in the Palmones river estuary. Estuar Coast Shelf Sci 39:461-476

Herrmann J-P, Jansen S, Temming A (1998) Fische und dekapode Krebse in der Sylt-Rømø Bucht. In: Gätje Ch, Reise K (eds) Ökosystem Wattenmeer Austausch-, Transport- und Stoffumwandlungsprozesse. Springer, Berlin Heidelberg New York, pp $81-88$

Higelke B (1998) Morphodynamik des Lister Tidebeckens. In: Gätje Ch, Reise K (eds) Ökosystem Wattenmeer Austausch-, Transport- und Stoffumwandlungsprozesse. Springer, Berlin Heidelberg New York, pp 103-126

Hughes RG, Lloyd D, Ball L, Emson D (2000) The effects of the polychaete Nereis diversicolor on the distribution and transplantation success of Zostera noltii. Helgol Mar Res 54:129-136

Ibarra-Obando SE, Boudouresque CF, Roux M (1997) Leaf dynamics and production of a Zostera marina bed near its southern distributional limit. Aquat Bot 58:99-112

Isaksson I, Pihl L (1992) Structural changes in benthic macrovegetation and associated epibenthic faunal communities. Neth J Sea Res 30:131-140

Jernakoff P, Nielsen J (1998) Plant-animal associations in two species of seagrasses in Western Australia. Aquat Bot 60: 359-376

Jespersen M, Rasmussen E (1994) Koresand - die Entwicklung eines Außensandes vor dem dänischen Wattenmeer. Die Küste 56:79-91

Johnson P, Johnstone R (1995) Productivity and nutrient dynamics of tropical seagrass communities in Puttalam lagoon, Sri Lanka. Ambio 24:411-417

Jonge VN de, Jong DJ de (1992) Role of tide, light and fisheries in the decline of Zostera marina L. in the Dutch Wadden Sea. Neth Inst Sea Res Publ Ser 20:161-176

Kalejta B, Hockey PAR (1991) Distribution, abundance and productivity of benthic invertebrates at the Berg River Estuary, South Africa. Coast Shelf Sci 33:175-191 
Kamermans P, Hemminga MA, Jong DJ de (1999) Significance of salinity and silicon levels for growth of a formerly estuarine eelgrass (Zostera marina) population (Lake Grevelingen, The Netherlands). Mar Biol 133:527-539

Katwijk MM van, Vergeer LHT, Schmitz GHW, Roelofs JGM (1997) Ammonium toxocity in eelgrass Zostera marina. Mar Ecol Prog Ser 157:159-173

Koch EW (1999) Sediment resuspension in a shallow Thalassia testudinum banks ex König bed. Aquat Bot 65:269-280

Kraemer GP, Mazzella L, Alberte RS (1997) Nitrogen assimilation and partitioning in the Mediterranean seagrass Posidonia oceanica. Mar Ecol 18:175-188

Kristensen E, Jensen MH, Jensen KM (1998) Sulfur dynamics in sediments of Königshafen. In: Gätje C, Reise K (eds) Ökosystem Wattenmeer, Austausch-, Transport- und Stoffumwandlungsprozesse. Springer, Berlin Heidelberg New York, pp 233-256

Lackschewitz D (1998) Besiedlungsmuster des Makrobenthos im Sylt-Römö-Wattenmeer. Abschlußbericht Sylter Wattenmeer Austauschprozesse, pp 1-52

Lapointe BE (1989) Macroalgal production and nutrient relations in oligotrophic areas of Florida Bay. Bull Mar Sci 44:312-323

Lapointe BE, Tomasko DA, Matzie WR (1994) Eutrophication and trophic state classification of seagrass communities in the Florida Keys. Bull Mar Sci 54:696-717

Lent F van, Nienhuis PH, Verschuure JM (1991) Production and biomass of the seagrass Zostera noltii Hornem. and Cymodocea nodosa (Ucria) Aschers. at the Banc d'Arguin (Mauritania, NW Africa): a preliminary approach. Aquat Bot 41: 353367

Lent F van, Verschuure JM, Veghel MLJ van (1995) Comparative study on populations of Zostera marina L. (eelgrass): in situ nitrogen enrichment and light manipulation. J Exp Mar Biol Ecol 185:55-76

Livingston RJ, McGlynn SE, Niu X (1998) Factors controlling seagrass growth in a Gulf coastal system: Water and sediment quality and light. J Exp Mar Biol Ecol 60:135-159

Madsen J (1988) Autumn feeding ecology of herbivorous wildfowl in the Danish Wadden Sea, and impact of food supplies and shooting on movements. Dan Rev Game Biol 13:1-32

Middelboe M, Kroer N, Jørgensen NOG, Pakulski D (1998) Influence of sediment on pelagic carbon and nitrogen turnover in a shallow Danish estuary. Aquat Microb Ecol 14:81-90

Moriarty DJW, Iverson RL, Pollard PC (1986) Exudation of organic carbon by the seagrass Halodule wrightii Aschers. and its effect on bacterial growth in the sediment. J Exp Mar Biol Ecol 96:115-126

Murphey PL, Fonseca MS (1995) Role of high and low energy seagrass beds as nursery areas for Penaeus duorarum in North Carolina. Mar Ecol Prog Ser 121:91-98

Nacken M. (1998) Einfluß der Sedimentverwühlungen von Ringelgänsen und Pfeifenten auf die Seegraswiesen und deren Makrofauna im Wattenmeer. Diplomarbeit Universität Bremen, pp 1-73

Nienburg W (1927) Zur Ökologie der Flora des Wattenmeeres I. Teil. Der Königshafen bei List auf Sylt. Helgol Wiss Meeresunters NF Abt Kiel, pp 149-196

Nienhuis PH (1992) Ecology of coastal lagoons in the Netherlands (Veerse Meer and Grevelingen). Vie Milieu 42:59-72

Nienhuis PH, Bree BHH de, Herman PMJ, Holland MB, Verschuure JM, Wessel EGJ (1996) Twenty five years of changes in the distribution and biomass of eelgrass, Zostera marina, in Grevelingen lagoon, The Netherlands. Neth J Aquat Ecol 30:107117

Olesen B, Sand-Jensen K (1994) Demography of shallow eelgrass (Zostera marina) populations - shoot dynamics and biomass development. J Ecol 82: 379-390

Orth RJ, Moore KA (1983) Chesapeake Bay: an unprecedented decline in submerged aquatic vegetation. Science 222:51-53

Orth RJ, Heck, KL, Montfrans J van (1984) Faunal communities in seagrass beds: a review of the influence of plant structure and prey characteristics on predator-prey relationships. Estuaries 7:339-350
Pedersen MF, Borum J (1992) Nitrogen dynamics of eelgrass Zostera marina during late summer period of high growth and low nutrient availability. Mar Ecol Prog Ser 80:65-73

Pedersen MF, Borum J (1993) An annual nitrogen budget for a seagrass Zostera marina population. Mar Ecol Prog Ser 101:169-177

Pedersen M, Paling EI, Walker DI (1997) Nitrogen uptake and allocation in the seagrass Amphibolis antarctica. Aquat Bot 56:105-117

Pérez M, Romero J (1993) Preliminary data on alkaline phosphatase activity associated with Mediterranean seagrasses. Bot Mar 36:499-502

Pérez-Lloréns JL, Niell FX (1995) Short-term phosphate uptake kinetics in Zostera noltii Hornem: a comparison between excised leaves and sediment-rooted plants. Hydrobiologia 297:17-27

Pérez-Llorens JL, Visscher P de, Nienhuis PH (1993) Light-dependent uptake, translocation and foliar release of phosphorus by intertidal seagrass Zostera noltii Hornem. J Exp Mar Biol Ecol 166:165-174

Pergent G, Pergent-Martini C (1990) Some applications of lepidochronological analysis in the seagrass Posidonia oceanica. Bot Mar 33:299-310

Philippart CJM (1995) Seasonal variation in growth and biomass of an intertidal Zostera noltii stand in the Dutch Wadden Sea. Neth J Sea Res 33:205-218

Phillips RC (1984) Ecology of eelgrass meadows in the Pacific Northwest: a community profile. Biol Ser Prog US Fish Wildlife Service

Phillips RC, Meñez EG (1988) Seagrasses. Smithsonian Contribution to the Marine Sciences. Smithsonian Institution Press, Washington, DC, no 34, pp 1-104

Pollard PC, Kogure K (1993) Bacterial decomposition of detritus in a tropical seagrass Syringodium isoetifolium ecosystem, measured with Methyl-3H thymidine. Aust J Mar Freshwater Res 44:155-172

Prieto MC, Corredor JE (1984) Studies of nitrogen cycling with experimental benthic chambers incubations. Proc Assoc Isl Lab Carrib 18:3

Reise K (1982) Long term changes in the macrobenthic invertebrate fauna of the Wadden Sea: are polychaetes about to take over? Neth J Sea Res 16:29-36

Reise K (1988) Plathelminth diversity in littoral sediments around the island of Sylt in the North Sea. Prog Zool 36:469-480

Reise K (1998) Coastal change in a tidal backbarrier basin of the northern Wadden Sea: are tidal flats fading away? Senckenberg Marit 29:121-127

Reise K, Lackschewitz D (1998) Benthos des Wattenmeeres zwischen Sylt und Rømø. In: Gätje Ch, Reise K (eds) Ökosystem Wattenmeer Austausch-, Transport- und Stoffumwandlungsprozesse. Springer, Berlin Heidelberg New York, pp 55-64

Reise K, Herre E, Sturm M (1989) Historical changes in the benthos of the Wadden Sea around the island of Sylt in the North Sea. Helgol Meeresunters 43:417-433

Reise K, Herre E, Sturm M (1994) Biomass and abundance of macrofauna in intertidal sediments of Königshafen in the northern Wadden Sea. Helgol Meeresunters 48:201-215

Reyes J, Sansón M, Afonso-Carillo J (1995) Leaf phenology, growth and production of the seagrass Cymodocea nodosa at El Médano (South of Tenerife, Canary Islands). Bot Mar 38:457-465

Riebensahm S (1981) Turbellarien in den Seegraswiesen des nordfriesischen Wattenmeeres. Schriftliche Hausarbeit im Rahmen der wissenschaftlichen Prüfung für das Lehramt an Gymnasien. pp $1-57$

Riesen W, Reise K (1982) Macrobenthos of the subtidal Wadden Sea: revisited after 55 years. Helgol Meeresunters 35:409-423

Rimmelin P, Dumon JC, Maneux E, Gonçalves A (1998) A study of annual and seasonal dissolved inorganic nitrogen inputs into the Arcachon Lagoon, Atlantic Coast (France). Estuar Coast Shelf Sci 47:649-659

Romero J, Pérez M, Mateo MA, Sala E (1994) The belowground organs of the Mediterranean seagrass Posidonia oceanica as a biogeochemical sink. Aquat Bot 47:13-19 
Sachs L (1983) Angewandte Statistik - Anwendung statistischer Methoden. Springer, Berlin Heidelberg New York

Scheiffarth G, Nehls G (1997) Consumption of benthic fauna by carnivorous birds in the Wadden Sea. Helgol Meeresunters 51:373-387

Schneider FI, Mann KH (1991) Species specific relationships of invertebrates to vegetation in a seagrass bed. I. Correlational studies. J Exp Mar Biol Ecol 145:101-117

Schomburg P (1997) Einfluß von Seegrasbewuchs (Zostera spec.) auf das Vorkommen mobiler Epifauna im Sand-und Schlickwatt vor Kampen, Sylt. Diplomarbeit Universität Bremen, pp 1-94

Short FT, McRoy P (1984) Nitrogen uptake by leaves and roots of the seagrass Zostera marina L. Bot Mar 27:547-555

Short FT, Short CA (1984) The seagrass filter: purification of estuarine and coastal waters. In: Kennedy VS (ed) The estuary as a filter. Academic Press, New York, pp 269-322

Short FT, Burdick DM, Kaldy JE (1995) Mesocosm experiments quantify the effects of eutrophication on eelgrass, Zostera marina. Limnol Oceanogr 40:740-749

Sogard SM, Able KW (1991) A comparison of eelgrass, sea lettuce macroalgae, and marsh creeks as habitats for epibenthic fishes and decapods. Estuar Coast Shelf Sci 33:501-519

Somaschini A, Gravina MF, Ardizzone GD (1994) Polychaete depth distribution in a Posidonia oceanica bed (rhizome and matte strata) and neighbouring soft and hard bottoms. Mar Ecol 15:133-151

Stapel J, Aarts TL, Duynhoven BHM van, Groot JD de, Hoogen PHW van den, Hemminga M (1996) Nutrient uptake by leaves and roots of the seagrass Thalassia hemprichii in the Spermode Archipelago, Indonesia. Mar Ecol Prog Ser 134:195206

Strieb MD, Bricelj VM, Bauer SI (1995) Population biology of the mud crab, Dyspanopeus syai, an important predator of juvenile bay scallops in Long Island (USA) eelgrass beds. J Shellfish Res 14:347-357

Suhr I (1996) Einfluß von Seegrasbewuchs (Zostera spec.) auf die Endobenthosbesiedlung von Sand- und Schlickböden (Sylter Rückseitenwatt). Diplomarbeit Universität Bremen, pp 1-88

Taylor D, Nixon S, Granger S, Buckley B (1995a) Nutrient limitation and the eutrophication of coastal lagoons. Mar Ecol Prog Ser 127:235-244

Taylor DI, Nixon SW, Granger SL, Buckley B, McMahon JP, Lin HJ (1995b) Responses of coastal lagoon plant communities to different forms of nutrient enrichment - a mesocosm experiment. Aquat Bot 52:19-34

Terrados J, Ros JD (1992) Growth and primary production of $C y$ modocea nodosa (Ucria) Ascherson in a Mediterranean coastal lagoon: the Mar Menor (SE Spain). Aquat Bot 43:63-74

Thommeret Y (1985) Activites scientifiques du laboratoire de radioactivité appliquée de 1960 à 1983. Bull Cent Sci Monaco $1: 1-78$
Tomasko, DA, Lapointe BE (1991) Productivity and biomass of Thalassia testudinum as related to water column nutrient availability and epiphyte levels: field observations and experimental studies. Mar Ecol Prog Ser 75:9-17

Udy JW, Dennison WC (1997) Growth and physiological responses of three seagrass species to elevated sediment nutrients in Moreton Bay, Australia. J Exp Mar Biol Ecol 217:253-277

Valentine JF, Heck KL Jr (1993) Mussels in seagrass meadows: their influence on macroinvertebrate abundance and secondary production in the northern Gulf of Mexico. Mar Ecol Prog Ser 96:63-74

Valentine JF, Heck KL, Harper P, Beck M (1994) Effects of bioturbation in controlling turtlegrass (Thalassia testudinum Banks ex König) abundance: evidence from field enclosures and observations in the Northern Gulf of Mexico. J Exp Mar Biol Ecol 178:181-192

Viaroli P, Bartoli M, Bondavalli C, Christian RR, Giordani G, Naldi M (1996) Macrophyte communities and their impact on benthic fluxes of oxygen, sulphide and nutrients in shallow eutrophic environments. Hydrobiologia 329:105-119

Walker DI, McComb AJ (1992) Seagrass degradation in Australian coastal waters. Mar Pollut Bull 8:191-195

Ward LG, Kemp WM, Boynton WR (1984) The influence of waves and seagrass communities on suspended particulates in an estuarine embayment. Mar Geol 59:85-103

Webb DG, Parsons TR (1991) Impact of predation-disturbance by large epifauna on sediment-dwelling harpacticoid copepods: field experiments in a subtidal seagrass bed. Mar Biol 109: 485-491

Williams SL (1990) Experimental studies of Caribbean seagrass bed development. Ecol Monogr 60:449-469

Wohlenberg E (1935) Beobachtungen über das Seegras Zostera marina L. und seine Erkrankung im nordfriesischen Wattenmeer. Beiträge zur Heimatforschung in Schleswig-Holstein, Hamburg und Lübeck 11:1-19

Wolff WJ, Land J van der, Nienhuis, PH, Wilde PAWJ de (1993) The functioning of the ecosystem of the Banc d'Arguin, Mauretania: a review. Hydrobiologia 258:211-222

Worcester SE (1995) Effects of eelgrass beds on advection and turbulent mixing in low current and low shoot density environments. Mar Ecol Prog Ser 126:223-232

Worthington DG, Ferrell DJ, McNeill SE, Bell JD (1992) Effects of shoot density of seagrass on fish and decapods: are correlations evident over large spatial scales? Mar Biol 112:139146

Yamamuro M, Koike I, Iizumi H (1993) Partitioning of the nitrogen stock in the vicinity of a Fijian seagrass bed dominated by Syringodium isoetifolium (Ascherson ) Dandy. Aust J Mar Freshwater Res 44:101-15

Zieman JC, Zieman RT (1989) The ecology of the seagrass meadows of the west coast of Florida: a community profile. US Fish Wildl Serv Biol Rep 87:7.25 